\title{
Historical and Legal Context and Significance of Selected Roman Public Law Institutions of the Early Principate Described in Canonical Gospels of the New Testament
}

\author{
MACIEJ TOMASZ KUBALA \\ University of Szczecin \\ maciej.kubala@usz.edu.pl \\ ORCID: 0000-0001-5475-1334
}

\begin{abstract}
The article analyses the issues in question by means of a method used in the legal sciences which in the Polish methodology is called "the historical and legal method." It involves presentation and analysis of selected legal institutions and of their evolution in time. The following issues - identified across the pages of the Gospel-are analysed in this article: political and systemic context of evangelical events (section 1), the role of censuses in the implementation of Roman administrative and systemic principles (section 2), Roman tax law in the context of tax burdens resting on residents of Judea (section 3) and the Roman judicial procedure in the context of the trial of Jesus (section 4). In the summary the author answers the research question asked in the introduction: to what degree does the historical and legal significance of selected institutions of Roman law, inspired by the description of these institutions in canonical gospels of the New Testament, determine the contemporary understanding of the gospels themselves?
\end{abstract}

KEYworDs: Gospel, Roman, Law, Institution, Imperium

T exts of canonical gospels of the New Testament we know today, written down from the first half of the first century, though recorded mainly to build the faith of first Christians and which is why they feature discrepancies in geography or chronology of historical events described, are the basic source of scholarly inquiry on the life and mission of Jesus of Nazareth, whose historicity has been confirmed — as admitted even by Rudolf Bultmann — also by non-Christian sources, anti-Christian in the most part. ${ }^{1}$

1 Cf. E. Dąbrowski, "Nowy Testament," CT 17/4 (1936) 530-550; cf. J. Kudasiewicz, "Ewangelie synoptyczne," Wstęp do Nowego Testamentu (ed. F. Gryglewicz) (Poznań: Pallottinum 1969) 61; cf. J. McDowell - B. Wilson, He Walked Among Us. Evidence for the Historical Jesus (Nashville: Nelson 1993); cf. J. McDowell, The New Evidence that Demands a Verdict (Nashville, TN: Nelson 1999) 33-68 and 119-136; examples of lay writings that provide historical evidence of Jesus of Nazareth, ibidem, 119-123: Cornelius Tacitus, Annals XV, 44; Lucian of Samosata, The Death of Peregrine, 11-13; Pliny the Younger, Epistles X, 96; Julius Africanus, Chronography 18.1 [quotes: Thallus, History of the Eastern Mediterranean World; Phlegon, Chronicles]; Mara Bar-Serapion [letter from prison to his son]; Flavius Josephus, The Antiquities of the Jews 18, 3, 3; cf. Ch.P. Paulus, Der Prozess Jesu - aus römisch-rechtlicher Perspektive (Berlin - Boston, MA: De Gruyter 2016) 1-2. 
As Joachim Jeremias wrote, "[...] the beginning of Christianity is not marked by kerygma, or the disciples' Easter experience or any idea of Christ; the beginning of Christianity is marked by a historical event, namely, an address by a man-Jesus of Nazareth, who was convicted by Pontius Pilate to death by crucifixion." Joachim Jeremias's thesis, put forward in the context of criticism and extreme historic scepticism of Formgeschichte, will also be interesting for a lawyer who does not only see the beginnings of the largest monotheistic religion in the world in the evangelical descriptions of the life and activity of Jesus of Nazareth, but also a precious source of information of systemic mechanisms of legal institutions applied then. ${ }^{3}$ The attempt made herein to assess the legal and historical significance of selected institutions of Roman law, inspired by the description of elements of these institutions in the canonical gospels of the New Testament, fits within a long tradition of scholarly pursuit (boasting effective solutions) of the presence of private and public law in the New Testament. ${ }^{4}$ Even though these searches mostly yield Jewish law and institutions, they also presents influences of various oriental and cuneiform laws, the Greek law and the Roman law. ${ }^{5}$ Henryk Kupiszewski and Marek Sobczyk point out that studies on Roman law in the New Testament mostly include historical and legal works on the trial of Jesus of Nazareth or the trial of St. Paul. ${ }^{6}$

This study applies a method of presentation of selected legal institutions of public law and their evolution in time (a method used in legal sciences and called

2 J. Jeremias, "Der gegnenwärtige Stand der Debatte um das Problem des historischen Jesus," Der historische Jesus und der kerygmatische Christus, 18-19 - as quoted in: Kudasiewicz, "Ewangelie synoptyczne," 63; cf. E. Dąbrowski, Proces Chrystusa w świetle historyczno-krytycznym (Poznań: Księgarnia św. Wojciecha 1965) 31-32.

3 A.N. Sherwin-White, Roman Society and Roman Law in the New Testament (Oxford: Clarendon 1963) 186-194.

4 Cf. E. Dąbrowski, Nowy Testament na tle epoki (Poznań: Księgarnia św. Wojciecha 1965); cf. Sherwin-White, Roman Society; cf. D. Nörr, "Civil Law in the Gospels," Irish Jurist 1/2 (1966) 328-340; cf. J. Duncan - M. Derret, Law in the New Testament (Eugene, OR: Wipf \& Stock 2005).

5 H. Kupiszewski, "Nowy Testament a historia prawa: (wykład z okazji pięćdziesięciolecia pracy naukowej ks. prof. dr Mariana Myrchy)," Prawo Kanoniczne 29/3-4 (1986) 13-26.

6 Kupiszewski, "Nowy Testament," 14: lists works by authors such as: Giuseppe Ricciotti (Życie Jezusa Chrystusa), Joseph Blinzler (Der Prozess Jesu), Jean Lambert (Le proces de Jesus); in vol. 25 of the series: Aufstieg und Niedergang der römischen Welt, works by: J. Duncan M. Derrett (Law and Society in Jesus/s World), Otto Betz (Probleme des Prozesses Jesu), or H.W. Kuhn (Die Kreuzesstrafe während der frühen Kaiserzeit. Ihre Wirklichkeit und Wertung in der Umwelt des Urchristentums). Cf. Duncan - Derret, Law in the New Testament, 389-461. The following studies in the Polish literature deserve a mention: Dąbrowski, Proces Chrystusa; P. Święcicka-Wystrychowska, Proces Jezusa w świetle prawa rzymskiego (Kraków: Wydawnictwo Uniwersytetu Jagiellońskiego 2005) - cited version [newest version: Warszawa: Wolters Kluwer 2012]; cf. M. Sobczyk, "Proces Jezusa oczami historyka i prawnika," Acta Iuridica Toruniensia 12 (2013) 221-252. About the trial of St. Paul: Kupiszewski, "Nowy Testament," 15: lists works by Theodor Mommsen, Rafael Taubenschlag, Arthur Steinwenter and the above-mentioned study by Adrian N. Sherwin-White; cf. E. Dąbrowski, Dzieje Pawta z Tarsu (Warszawa: Teologia Polityczna 2013). 
in the Polish scientific methodology: "historical and legal method"). Information included in the gospels on certain elements of public law institutions of systemic constructs of the Roman legal order of early principate that regulated day-to-day life of residents of Palestine contemporary to Jesus will be extended by a description and a broader analysis of their legal and historical context. The selection of the institutions of public law described, that at first glance may seem random, was made according to the key of chronology of events described in gospels due to the representativeness recognized by legal scholars and commentators. The methodological assumption to describe public law institutions excludes the possibility to analyze equally representative private law institutions, such as divorce law. The analyses will allow an answer to the following research question: to what extent does historical and legal significance of selected institutions of Roman law, inspired by the description of elements of these institutions in canonical gospels of the New Testament, determine the contemporary understanding of the gospels themselves.

\section{Roman Political and Systemic Context of Evangelical Events}

It is commonly recognized in the scholarship that Dionysius Exiguus, acting on request of Pope John I, miscalculated Jesus's date of birth (the beginning of the new era of Christianity) in the Paschal table at 25 December, 753 Ab Urbe condita (since the foundation of Rome). ${ }^{7}$ Avoiding commonly known details of scholarly discussion that led to establishing this, for the needs of this study it suffices to say that Jesus of Nazareth was born between 7 and 4 "before Christ." This finding is mainly reconstructed on the basis of two fragments of the Gospel: Luke 2:1 and Matt 2:1, which include historical information that allows placing the evangelical events in a specific political and systemic context. ${ }^{9}$

7 B. Altaner - A. Stuiber, Patrologia (Warszawa: Instytut Wydawniczy PAX 1990) 623-624.

$8 \quad$ Cf. E. Dąbrowski, Życie Jezusa Chrystusa w opisie ewangelistów (Poznań: Pallottinum 1951) 290-293; cf. M. Jaczynowska, Historia starożytnego Rzymu (Warszawa: Państwowe Wydawnictwo Naukowe 1974) 333.

9 R.E. Brown, The Birth of the Messiah. A Commentary on the Infancy Narratives in the Gospels of Matthew and Luke (New York: Doubleday 1977) 47-48; cf. Dąbrowski, Życie Jezusa, 292-293; cf. F. Mickiewicz, Ewangelia wedlug świętego Łukasza. Rozdzialy 1-11 (NKB.NT 3/1; Warszawa: Edycja Świętego Pawła 2010) 160 and 162; cf. A. Paciorek, Ewangelia wedlug świętego Mateusza. Rozdziały 1-13 (NKB.NT 1/1; Warszawa: Edycja Świętego Pawła 2010) 119-122. Bible passages as quoted in: The New Revised Standard Version of the Bible (NRSV), https://www.biblegateway.com/ versions/New-Revised-Standard-Version-NRSV-Bible/ [access: 30.06.2021]. 
This context, drafted in Mathew's account by reference to the figure of Herod the Great, is presented in the history of increasing dependence of Judea (conquered in $63 \mathrm{BC}$ by Pompey) on ancient Rome, which at that time was being transformed from a republic into an empire. The history of Herod's collaboration with the Romans points to many Roman legal and political details.

Herod's father, Antipater, having been awarded by Julius Caesar in $47 \mathrm{BC}$ the title of epitropos (procurator) at ethnarch John Hyrcanus II (Greek: the ruler of people, a title used in Hellenistic cultural circles to denote a monarch lower than a king), also obtained Roman citizenship and immense power in Judea. ${ }^{10}$ The office of the prosecutor was more important than the office of a prefect and it is worth noting that many years later (after banishing Archelaus, Antipater's grandson), when Judea officially became a Roman province, prefect-rank governors of this province were appointed (Coponius 6-9 AD, Marcus Ambivulus 9-12 AD, Annius Rufus 12-15 AD, Valerius Gratus 15-26 AD, Pontius Pilate 26-36 AD, Marcellus 36-37 AD and Marullus 37-41 AD) until the times of Emperor Claudius who in $44 \mathrm{AD}$ nominated Cuspius Fadus as governor of Judea in the procurator's rank. ${ }^{11}$

Antipater made Herod governor of Galilee, while his older brother Phasael was to govern Jerusalem and neighbouring lands. ${ }^{12}$ In 46 BC, Herod annexed Golan and Samaria to lands administered by him. ${ }^{13}$ After establishing a triumvirate, Marc Antony, governor of the east, decided that John Hyrcanus II would continue to be high priest ethnarch, while Herod and Phasael would continue to hold the positions of governors of their provinces with the tetrarch title ("ruler of a division of a country"), which corresponded to princedom. ${ }^{14}$ When the Parthians conquered Syria, Judea and the Middle East in $40 \mathrm{BC}$ and restored the rule of the Hasmonean dynasty, Herod had to flee Jerusalem. Not wanting to allow Roman's approval on the Jewish throne of Antigonus, allied with the Parthians, he pursued the honour and royal authority over Judea for his future brother-in-

10 P. Schäfer, The History of the Jews in the Greco-Roman World. The Jesus of Palestine from Alexander the Great to the Arab Conquest (London: Routledge 2003) 83.

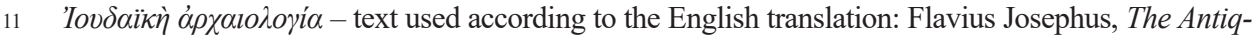
uities of the Jews [Ant.], https://www.documentacatholicaomnia.eu/03d/0037-0103,_Flavius_Josephus,_The_Antiquities_Of_The_Jews,_EN.pdf [access: 30.06.2021] 18, 3,3; 20, 1, 1-2; $20,5,1$; cf. Sherwin-White, Roman Society, 6; cf. M. Grant, Dzieje dawnego Izraela (Warszawa: Państwowy Instytut Wydawniczy 1991) 270; cf. Święcicka-Wystrychowska, Proces, 43-44; cf. J.I. Packer M.C. Tenney (eds.), Nelson's Illustrated Manners and Customs of the Bible - quoted in the Polish version: Stownik tta Biblii (Polish version edited by W. Chrostowski; trans. Z. Kościuk) (Warszawa: Vocatio 2007) 127-128.

12 J. Ciecieląg, Polityczne dziedzictwo Heroda Wielkiego. Palestyna wepoce rzymsko-herodiańskiej (Kraków: Wydawnictwo Naukowe Akademii Pedagogicznej w Krakowie 2002) 18, 20, 23, 35, 41-44.

13 J. Klinkowski, Herod Wielki i jego epoka (Wrocław: TUM 2007) 44.

14 Ciecieląg, Polityczne, 41-43. 
law, Aristobulus. However, he himself unanimously was appointed king of Judea by the $40 \mathrm{BC}$ Roman senate - on request of two-thirds of co-reigning creators of the triumvirate-Mark Antony (governor of the east) and Octavian (governor of the west). ${ }^{15} \mathrm{He}$ only took the throne in $36 \mathrm{BC}$ after a victory against Antigonus, which earned him an even greater favour from the Romans. ${ }^{16}$ Establishing Herod on the throne of Judea with the royal title meant the demise of the Hasmonean dynasty and handing over the power to the House of Idumeans, which in turn caused Jews' reluctance towards Herod, magnified by decisions such as dissolution of the Council of Elders or the death penalty executed on 50 out of 71 members of the Sanhedrin, which already at the time of his son Archelaus was the reason for the Jewish revolt called Varus's war. ${ }^{17}$ Herod suffered from severe depressive attacks during which he murdered friends and members of his own family. ${ }^{18}$ In $29 \mathrm{BC}$, he murdered one of his 10 wives - a beloved wife, who, nevertheless, was turning a Hasmonean princess Mariamne against him whom he had married to gain approval of the Jews. ${ }^{19}$ Earlier-to get rid of rivals to the throne - he got the Roman death conviction for his sons with MariamneAlexander and Aristobulus. He also drowned his brother-in-law Aristobulus and had his uncle Joseph executed on charges of adultery. ${ }^{20}$ Just before his death he also killed his first-born son Antipater, whom he had appointed his successor in his will, which he had proclaimed earlier in Jerusalem. ${ }^{21}$

In $31 \mathrm{BC}$, Octavian's fleet defeated Mark Antony and Cleopatra in the Battle of Actium. ${ }^{22}$ In $29 \mathrm{BC}$, Octavian placed his supporters on the list of senators and himself on the first place as princeps senatus. ${ }^{23}$ On 31 January 27 BC, Octavian announced at the senate's session that he renounced the office of triumvir and that he wanted to restore the republic. Senators-Octavian's supportersinsisted that he keep his full power and he "generously" shared the power with the senate. ${ }^{24}$ Thanks to this clever manoeuvre he gained imperium proconsulare (the authority of proconsul as provincial governor) which gave him actual power over the frontier provinces of Gaul, Spain and Syria, which combined with Egypt

15 W. Gnutek, “Środowisko Nowego Testamentu," Wstęp do Nowego Testamentu (ed. F. Gryglewicz) (Poznań: Pallottinum 1969) 17.

16 Gnutek, “Środowisko Nowego Testamentu,” 17; cf. Ciecieląg, Polityczne, 23, 42.

17 Grant, Dzieje, 262; cf. Josephus, Ant. 17, 10, 1; cf. Ciecieląg, Polityczne, 17.

18 Ciecieląg, Polityczne, 90-91; cf. Packer - Tenney, Stownik tta Biblii, 123.

19 Gnutek, "Środowisko Nowego Testamentu," 18-19.

20 Packer - Tenney, Stownik tta Biblii, 123.

21 Gnutek, "Środowisko Nowego Testamentu," 19.

22 J. Wolski, Historia Powszechna. Starożytność (Warszawa: PWN 1997) 384.

23 M. Jaczynowska - D. Musiał - M. Stępień, Historia starożytna (Warszawa: Trio 1999) 500; cf. A. Tarwacka, "Censoria potestas Oktawiana Augusta," Zeszyty Prawnicze UKSW 11/1 (2011) 359.

24 Tarwacka, "Censoria," 359; cf. Jaczynowska - Musiał - Stępień, Historia starożytna, 500. 
made him practically independent of the senate which was given the governance of long conquered internal provinces where no troops stationed. ${ }^{25}$

Gaining imperium proconsulare contributed to the increase of Octavian's auctoritas. He considered his position still not strong enough, which is why in $23 \mathrm{BC}$ he reorganized the basis of his authority and, giving up his permanent election as consul, he obtained extension of his proconsular power with imperium maius (the highest), also called perpetuum (perpetual), which allowed him to publish his edicta (proclamations) also in the provinces of the Roman people (provinciae populi romani), also called senatorial. ${ }^{26}$

Octavian's obtaining of imperium maius contributed to the changing of the understanding of the term imperium maius itself, which in the time of the republic meant "power understood as the law to issue instructions, power exercised in the holding of the highest offices, ${ }^{, 27}$ which was afforded to the highest state officials (consul, praetor, dictator or his magister equitum), with the distinction between imperium maius (consul's superior authority) and imperium minus (praetor's inferior authority) and from the times of Octavian Augustus imperium started to mean authority afforded to emperors. ${ }^{28}$ Researchers point out that this was also affected by the scope of power of officials sent as provincial administrators, who during the republic held the following competences: military authority (imperium militiae), the judiciary (imperium and iurisdictio) and a broadly understood civil and administrative power (i.a. ius edicendi, ius coercendi). ${ }^{29}$ The change meant that while populus romanus was the source of authority of a provincial administrator during the republic, at the beginnings of principate the auctoritas principis became this source. ${ }^{30}$ It was a princeps who gave his imperium to governors heading for provinces as his deputies. ${ }^{31}$ Despite this change, in the evangelical times, imperium of a provincial administrator, modelled on the republican proconsular imperium, does not know limitations such as mandata or rescripta, which specified the scope of authority of governors form the 2nd century onwards. A governor in this time was independent and was only supposed to refrain from abuses. ${ }^{32}$ Although he was allowed to accept minor gifts

25 Sherwin-White, Roman Society, 1-2; cf. Tarwacka, "Censoria," 359; cf. Wolski, Historia, 391.

26 Wolski, Historia, 392; cf. P. Zanker, Augustus und die Macht der Bilder, 3 ed. (München: Beck 1997) - quoted in the Polish version: August i potęga obrazów (eds. M. Jankowska - E. Dobosz, trans. L. Olszewski) (Poznań: Wydawnictwo Naukowe UAM 1999) 97-102.

27 W. Dajczak - T. Giaro - F. Longhamps de Bérier, Prawo rzymskie. U podstaw prawa prywatnego, 3 ed. (Warszawa: PWN 2018) 643.

28 K. Kolańczyk, Prawo rzymskie, 2 ed. (Warszawa: PWN 1976) 41-44; cf. Dajczak - Giaro - Longhamps de Bérier, Prawo, 643.

29 Święcicka-Wystrychowska, Proces, 48; cf. Kolańczyk, Prawo, 43.

30 Jaczynowska, Historia starożytnego Rzymu, 212-213; cf. Święcicka-Wystrychowska, Proces, 48.

31 cf. Święcicka-Wystrychowska, Proces, 48.

32 Kolańczyk, Prawo, 39-40. 
(not exceeding the use of food products), accepting or demanding greater gifts or setting additional levies was considered greed or exorbitance punishable under the 149 BC lex Calpurnia repetundarum. ${ }^{33}$

The civil basis of Octavian's power was the so-called tribunicia potestas, which gave him all entitlements of the Tribunes of the People. ${ }^{34}$ As a patrician (adopted by Julius Caesar; in reality grandson of Julia, Caesar's sister) he could not be a usual tribune of people, and thanks to lex Saenia (30 BC), he could appoint new patricians who were to replenish the ranks of representatives of old patrician houses..$^{35}$ Thanks to tribunicia potestas, Octavian Augustus should summon meetings of the senate and of comicia (people's assembly). ${ }^{36} \mathrm{He}$ also had priority in drawing conclusions and vetoing senate's resolutions or requests contrary to his policy brought to the assemblies..$^{37}$ Octavian Augustus' other rights included, e.g.: (a) pontifex maximus - the office of the highest priest held by Octavian from $12 \mathrm{BC}$, whose task was to oversee general religious life, (b) ius commendationis - the right to present candidates for the highest official positions, or (c) cura annonae - ensuring supply of grain to Rome and Italia. ${ }^{38}$ Prefects - officials delegated by him - helped the princeps to fulfil these functions. ${ }^{39}$ As part of tribunicia potestas, he also exercised some tasks that rested with censors already during the republic, such as cura morum, though he never called himself a censor, wanting to keep the appearance of respecting republican institutions..$^{40}$ Lex de imperio - a right to pass a resolution (senatus consulta) that gives the emperor imperium and lists various imperial prerogatives, acted as a certain counterbalance, though systemically not truly effective, for princeps' extensive authority. ${ }^{41}$ Lex de imperio was the right afforded to the senate which gained advantage as a result of disappearance of comitiorum. By virtue of lex de imperio, the senate could, also after the death of a princeps, approve or reject statutes passed during his reign. ${ }^{42}$ Total subordination of the princeps to the senate caused that, de facto it was he himself who specified the scope of imperium that was in his disposal.

The systemic principle of co-governance (Greek dyarchia) of the princeps and the senate, therefore, became fiction which allows us to talk about the factual beginning of monarchical power in Rome from $27 \mathrm{BC} .^{43}$ So understood politi-

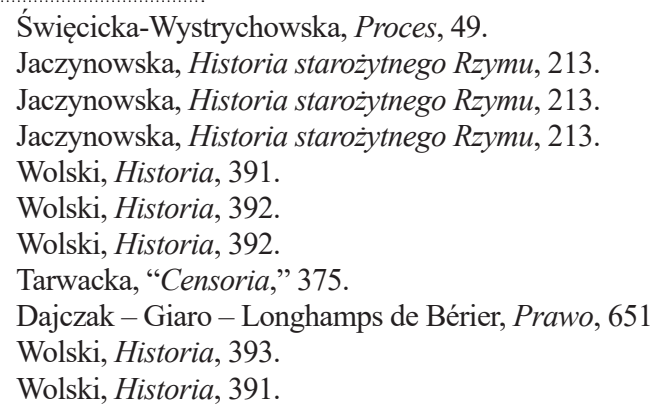


cal system created by Octavian - called principate by Theodor Mommsen-was upheld until the taking of power by Diocletian in $284 \mathrm{AD}$, thus it characterises the system in the times described in evangelical events, closed by the reign of the first two emperors-Octavian Augustus (30 BC - 14 AD) and Tiberius (14-37 AD). ${ }^{44}$ A certain general political and economic characterization of this period is also reflected in Pax Romana, which means the time from the victory of Actium till $180 \mathrm{AD}$ (or even later according to some authors - the death of Severus Alexander, that is $235 \mathrm{AD}$ ), presented in the literature as a time of peace, economic development and efficient governance when at the same time manufacturing activity flourished in Roman provinces. ${ }^{45}$ Octavian Augustus allowed the conquered nations to keep their own language, customs and religion as long as their people lived in peace with Rome. ${ }^{46}$ Since independence-desiring Jews had a rebellious attitude towards the Romans, Octavian Augustus needed the handy Herod, who - initially involved on the side of Mark Antony and Cleopatra only thanks to Cleopatra's intrigues (during a war between Antony and Octavian, she convinced Antony to send Herod against the Nabataeans instead of relying on his support because she wanted to weaken Herod's kingdom and absorb it)—did not fight against Octavian, which is why after the victory Herod could pay homage to him on the island of Rhodes and maintain his rule in Judea ${ }^{47}$ Until the end of his life, Herod maintained friendly client relations with Octavian Augustus, which was beneficial for his client kingdom. Herod was able to appear both as Rome's friend and as a good Jew caring for his people who, for example, in $20 \mathrm{BC}$, started building a new Temple in Jerusalem that we hear of in evangelical messages (Matt 4:5, Mark 11:27, Luke 19:45, John 2:14). ${ }^{48}$

After Herod's death in $4 \mathrm{BC}$, Octavian Augustus cancelled the title and honour of king and the Kingdom of Judea was divided between Herod the Great's four surviving sons, that is Herod Archelaus with the title of an ethnarch and Herod Antipas and Herod Philip who held titles of tetrarchs. ${ }^{49}$ Herod Boethus Philip, known in the gospels as an estranged husband of Herodias, was disinherited by his father in $5 \mathrm{BC}$ and spent the rest of his life in Rome. ${ }^{50}$ Archelaus was given the governance - with the ethnarch title — of northern Idumea, combined with Judea with its capital in Jerusalem, and Samaria. ${ }^{51}$ Antipas was given the re-

44 Jaczynowska - Musiał - Stępień, Historia starożytna, 673-674.

45 M. Jońca, Prawo rzymskie. Mirabilia (Warszawa: Beck 2020) 89-90; cf. J. Wolski, "Przedmowa," Prowincje rzymskie i ich znaczenie w ramach Imperium (eds. M. Jaczynowska - J. Wolski) (Warszawa: Zakład Narodowy im. Ossolińskich - PAN 1976) 5-6; cf. Mickiewicz, Ewangelia, 161-162.

46 Packer - Tenney, Stownik tta Biblii, 123.

47 Packer - Tenney, Stownik tła Biblii, 123.

48 Grant, Dzieje, 263; cf. Packer - Tenney, Stownik tta Biblii, 123.

49 Gnutek, "Środowisko Nowego Testamentu," 19.

50 Grant, Dzieje, 269.

51 Gnutek, "Środowisko Nowego Testamentu," 19. 
maining northern part of Palestine, Galilee located west of Jordan and Perea, east of Jordan at the height of Judea proper. It is Antipas who gained recognition for wanting to execute John the Baptist who reprimanded him due to his concubinage with Herod Boethus Philip's wife, called Herodias in the gospels (Mark 6:14-29; Matt 14:5-12). ${ }^{52}$ Philip was given the possession of lands east and north-east of Jerusalem - between the river and Mount Hermon - called Trachonitis, Gaulanitis, Batanea and Hauran (Auranitis). ${ }^{53}$ Herod the Great's grandson, Herod Agrippa I (son of the murdered Aristobulus), also appears in the evangelical events and so does Herod Agrippa II, son of Agrippa I. ${ }^{54}$

While Antipas successfully ruled until 39 AD, and Philip till 34 AD, the reign of Archelaus, due to his despotism, lasted only 10 years because Octavian Augustus, owing to complaints from desperate residents of Judea and Samaria, took Archelaus's power away and sent him into exile in $6 \mathrm{AD}$. From that moment, Judea became a minor Roman imperial province, with the capital city in Caesarea Maritima administered by the equites in the rank of - as mentioned above-prefects and then, from $44 \mathrm{AD}$, procurators. The Roman status of the equites from which governors of the Judea province derived was higher than the status of senators who administered more important provinces. Judea as a province answered to the equites and had minute military resources ( 5 cohorts of the infantry and 1 cohort of quasi-cavalry, 500 to 1,000 soldiers each). ${ }^{55}$ The military troops stationed largely in Palestine's two main Roman cities: Sabaste in Samaria and Cesarea-Herod's main maritime harbour (Acts 10:1). A legion permanently stationed in the Antonia Fortress which neighboured the Jerusalem temple and during religious holidays a large number of soldiers were transferred to Jerusalem to ensure order among pilgrims and to prevent riots that may have been ignited by the Jewish party. ${ }^{56}$ These were the so-called auxiliary divisions that mostly recruited local pagan people. One of the cohorts was recruited among Roman citizens - volunteers (Cohors II civium Romanorum voluntariorum). ${ }^{57}$ When military reinforcements were necessary, the governor of Judea requested Syria's military support. ${ }^{58}$ Jews who were supporters of military service had a paramilitary division of temple guard (cf. Matt 26:47; John 18:31). ${ }^{59}$

52 Cf. Duncan - Derret, Law in the New Testament, 339-362; cf. Packer - Tenney, Stownik tta Biblii, 125; cf. M. Jońca, Głośne rzymskie procesy karne (Wrocław: Zakład Narodowy im. Ossolińskich 2009) 188; cf. A. Paciorek, Ewangelia wedtug świętego Mateusza. Rozdziaty 14-28 (NKB.NT 1/2; Warszawa: Edycja Świętego Pawła 2010) 23-38.

53 Gnutek, "Środowisko Nowego Testamentu," 19.

54 Gnutek, "Środowisko Nowego Testamentu," 19, 23-24.

55 Święcicka-Wystrychowska, Proces, 47; cf. Packer - Tenney, Stownik tta Biblii, 126.

56 Josephus, Ant. 20, 5, 3; cf. Packer - Tenney, Stownik tta Biblii, 126; cf. Jońca, Gtośne, 189.

57 Święcicka-Wystrychowska, Proces, 47.

58 Grant, Dzieje, 269-270.

59 Packer - Tenney, Stownik tta Biblii, 126. 
When we say province, we mean-as defined by Tacitus or Julius Caesar-a subordinate territory which is under military occupation, from which taxes are regularly collected and public order and organization of power fall under the jurisdiction of the province administrator (proconsul in provinces of the Roman people and a legate or equites governor in imperial provinces, i.e. prefect and later procurator in Judea).$^{60}$ Residents of the province of Judea were free but did not hold Roman citizenship unless granted to them by a special act of authority. They were accommodated within the category of foreigners (peregri$n i$ ). Even though they had to observe the rules prescribed by the Romans, they could live according to their own laws. The organization of the Judea province was regulated by, like was the case of other provinces, lex provinciae-rules of administration of a given province, relating to existing rules of the people conquered. ${ }^{61}$ Even though Judea had the opinion of a rebellious province and could not wish for loosening of the occupational rigour, in $8 \mathrm{AD}$ Octavian Augustus issued a special edict in which he confirmed Jews' privileges. ${ }^{62}$ Flavius Josephus reports that the emperor had decided "that the Jews have liberty to make use of their own customs according to the law of their forefathers, as they made use of them under Hyrcanus the high priest of the Almighty God." ${ }^{93}$ The Jewish religion gained the status of religio licita, that is legally permitted, which gave Jews the right to build synagogues, to practise religion freely and they themselves as a nation were officially exempt from the obligation to participate in ceremonies related to national worship. ${ }^{64}$ The Romans appointed the president of the Sanhedrin - main Jewish political body and the high priest. ${ }^{65}$ The high priests of evangelic times included Ananus, known from the gospels (Luke 3:2; John 8:13.24) and appointed by Quirinius, who was forced to resign following the death of Octavian Augustus in $14 \mathrm{AD}$, and those appointed by Gratus who do not appear in the gospels: Ishmael ben Fabus (15-16), Eleazar ben Ananus (16-17) and Simon ben Camithus (17-18). Joseph ben Caiaphas (18-36), known from Jesus' trial, was also a high priest. ${ }^{66}$ The Sanhedrin was a religious court and the high priest was the superior of priesthood ${ }^{67}$ Jews were exempt from military service, they were not called to appear before courts on Sabbath, and images of the emperor or sculptures of Roman gods were not put on display in Jerusalem. ${ }^{68}$ Nevertheless,

\footnotetext{
60 Święcicka-Wystrychowska, Proces, 44.

61 Święcicka-Wystrychowska, Proces, 45.

62 Jońca, Głośne, 184; cf. Dąbrowski, Proces Chrystusa, 91.

63 Josephus, Ant. 16, 6, 2

64 Josephus, Ant. 19, 5, 2; cf. Jońca, Głośne, 185; cf. Święcicka-Wystrychowska, Proces, 46-47.

65 Packer - Tenney, Stownik tła Biblii, 127.

66 Entry: "High Priest," Jewish Encyclopedia (The unedited full-text of the 1906 Jewish Encyclopedia) https://www.jewishencyclopedia.com/articles/7689-high-priest [access: 18.06.2021].

67 Packer - Tenney, Stownik tła Biblii, 127.

68 Jońca, Głośne, 184; cf. Święcicka-Wystrychowska, Proces, 46.
} 
they were subject to censuses and their day-to-day lives and possessions were constantly controlled by the occupant.

\section{Censuses and Implementation of Roman Administrative and Systemic Principles in the Territory of Judea}

The term $\dot{\alpha} \pi \sigma \gamma \rho \alpha \varphi \eta^{\prime}$ (registration) used in Luke's account refers to the institution of Roman law which corresponds to the Latin term census, us, which means filling out lists containing a registration of citizens and their possessions ${ }^{69}$ According to tradition, the first registration is associated with the first timocratic reform (a political principle seen in e.g. Solon of Athens who used it to replace the aristocratic principle by grading political rights depending on estimated wealth levels), ${ }^{70}$ conducted by Servius Tullius (578-535 BC) who classified Roman citizens according to their wealth, dignity, age, profession and function and placed these categories in public registers of citizens. ${ }^{71}$ Thanks to the census done every five years which covered all patres familias, it was possible to establish the economic and personal status of families which was the basis for calculating financial burdens imposed on them and to assign them with relevant military units called centuria. ${ }^{72}$ After the Servian reform, the entire Roman population was divided into 5 economic classes ( 6 if we count proletaria). What is more, under individual classes there was an internal division into centurie which in the period of the republic gained a political character since voting in centuriate assemblies (comitia centuriata) was not direct, but votes belonged to a centuria. ${ }^{73}$ Initially censuses were conducted by consules. ${ }^{74}$ From the establishment of the office of a censor in $443 \mathrm{BC}$, the census was carried out by those officials. Two censors were chosen among patricians by comitia centuriata every five years for the period of a one and half years, and from 339 AD (Lex Publilia Philonis de censore

69 Greek version of the Bible as quoted in the critical study by Nestle Alland, https://www.academic-bible.com/en/online-bibles/novum-testamentum-graece-na-28/read-the-bible-text/bibel/text/ lesen/stelle/52/20001/29999/ch/13ed9990af418d2300e3bfe7ecb2963f/ [access: 30.06.2021]; cf. Entry: "census," Treccani. Vocabolario on-line, https://www.treccani.it/vocabolario/censo/ [access: 30.06.2021]; cf. Entry: “Census,” Stownik tacińsko-polski (ed. M. Plezia) (Warszawa: PWN 2007) I, 475.

70 B. Bravo, "Reformy Polityczne Solona a struktura wspólnoty obywateli ateńskich w okresie archaicznym," Przeglad Historyczny 87/2 (1996) 169-170.

71 E. Lo Cascio, "Il census a Roma e la sua evoluzione dall'età serviana alla prima età imperiale," MEFR 113/2 (2001) 590 .

72 Lo Cascio, "Il census," 571-572.

73 W. Wołodkiewicz (ed.), Prawo rzymskie. Stownik encyklopedyczny (Warszawa: Wiedza Powszechna 1986) 31.

74 Wołodkiewicz, Prawo, 31. 
credendo) one censor was to come from the plebs. ${ }^{75}$ The office of a censor started to deteriorate under Sulla and according to Suetonius, who names two last censors: Plancus and Paulus in $22 \mathrm{BC}$, there were no censors from $47 \mathrm{AD}$ and the office was reborn in a different form under emperor Claudius. ${ }^{76}$

The census, cancelled during Sulla's dictatorship (82-79 BC) and restored by Octavian Augustus, gained increasing importance for the political order of the entire empire. ${ }^{77}$ According to Res gestae Divi Augusti, Octavian Augustus performed three registrations of Roman citizens in the empire, first one together with Agrippa in $28 \mathrm{BC}$, the second census by himself in $8 \mathrm{BC}$, and the third, towards the end of his reign, together with Tiberius, in $14 \mathrm{AD} .{ }^{78}$ Reflections on the office of the censor are helpful here, because we cannot be sure if the competence that allowed Octavian to perform the registration was censoria potestas or perhaps imperium. According to Anna Tarwacka Octavian Augustus "must have adopted censoria potestas in $29 \mathrm{BC}$ to conduct the census. It was necessary because his colleague Agrippa had not yet held consulate as he was only consul desingatus for the following year. Augustus carried out subsequent censuses by means of imperium he was afforded, referring to times when registrations were made - before the establishment of the office of the censor-by consuls." ${ }^{\prime 79}$

Next to censuses of Roman citizens, there were also provincial censuses intended to specify tax obligations of province residents who admittedly did not hold Roman citizenship, but carried the most tax burden in the Roman empire. ${ }^{80}$ These censuses were obligatory for all residents of a province aged 14 or older. During the census, information of the real property the family had, the type of profession practised and the number of people in the household had to be given. There is a mention of such a census in Luke 2:1-2. It has been historically proven that a census was performed in Egypt every 14 years. As noted by Marian Wolniewicz, "if censuses in Palestine took place every 14 years like in Egypt, the previous census in Palestine would have fallen for $8 \mathrm{BC}$, thus the same year

75 A. Tarwacka, Prawne aspekty urzędu cenzora w starożytnym Rzymie (Warszawa: Wydawnictwo UKSW 2012) 25-42; Wołodkiewicz, Prawo, 31, 40.

76 Tarwacka, "Censoria," 363.

77 Jaczynowska, Historia starożytnego Rzymu, 165-166.

78 Tarwacka, "Censoria," 359; cf. H. Braunert, "Der römische Provinzialzensus und der Schätzungsbericht des Lukas-Evangeliums," Historia 6 (1957) 192-193; cf. M. Wolniewicz, "Komentarz," Pismo Święte Starego i Nowego Testamentu w przekładzie z języków oryginalnych ze wstępami i z komentarzem, 2 ed. (ed. M. Wolniewicz) (Poznań: Księgarnia św. Wojciecha 1982) III, 154.

79 Tarwacka, "Censoria," 375.

80 E. Lo Cascio, "The Size of the Roman Population: Beloch and the Meaning of the Augustan Census Figures," JRS 84 (1994) 32; cf. Brown, The Birth, 549; cf. Lo Cascio, "Il census," 593-594. 
in which (at the end) Octavian Augustus ordered the second (general) census of Roman citizens." $" 1$

Flavius Josephus and the Acts, on the other hand, mention a census in Palestine which took place in $6 \mathrm{AD} .{ }^{82}$ Some of these fragments also mention Quirinius. At the end of Book 17 of Antiquitates, Flavius writes: "So Archelaus's country was laid to the province of Syria; and Quirinius, one that had been consul, was sent by Caesar to take account of people's effects in Syria, and to sell the house of Archelaus." ${ }^{83}$ The entire Chapter of Book 17 of Antiquitates is devoted to Quirinius's census and its political consequences such as rebellious attitudes among Jews. ${ }^{84}$ It is clear that Quirinius - unlike presented in Luke 2:1-2 - reached Syria in $6 \mathrm{AD}$ and his census also was held at the same time. Therefore, does Luke 2:1-2 talk about the $8 \mathrm{BC}$ census or the $6 \mathrm{AD}$ census?

We generally know the explanations of this discrepancy which take the date $8 \mathrm{BC}$ as certain and do not mention Flavius. They assume-after Tertullian - that the census was initiated by Sentius Saturninus and finished by Quirinius or, according to another idea, that Luke's gospel's editor, who had a historical perspective, attributed authorship of the census to Quirinius because he was a well-known figure. ${ }^{85}$ Exegetes also point out that the expression Kvpqviov

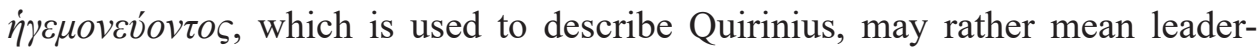
ship in the war against the Homonads, which also gave a special authorisation to perform censuses and to collect taxes. Mucianus was Syria's legate in this war against Jerusalem and military leadership was in the hands of Vespasian. Biblical scholars point out that it is linguistically legitimate to translate the fragment

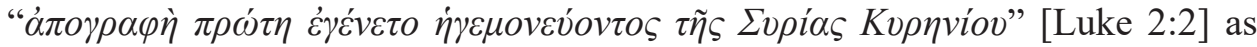
"This census took place before Quirinius became governor of Syria" (instead of: "while" or "at the time when"). ${ }^{86}$ Assuming that $8 \mathrm{BC}$ is the correct date of the census, we must solve the puzzle and explain the fact that Herod the Great was still alive then and Judea was not a Roman province but a dependent state, therefore Jews were not obliged yet to take part in the census. Some authors believe that client states such as Judea were constantly divided, merged, incorporated in total and in part to provinces or extracted from them. ${ }^{87}$

For this reasons most researchers think it more likely that Luke 2:1-2 refers to the $6 \mathrm{AD}$ census, wrongly pinpointing Jesus's birth still during the life of Herod the Great. The adoption of such interpretation is also advocated by

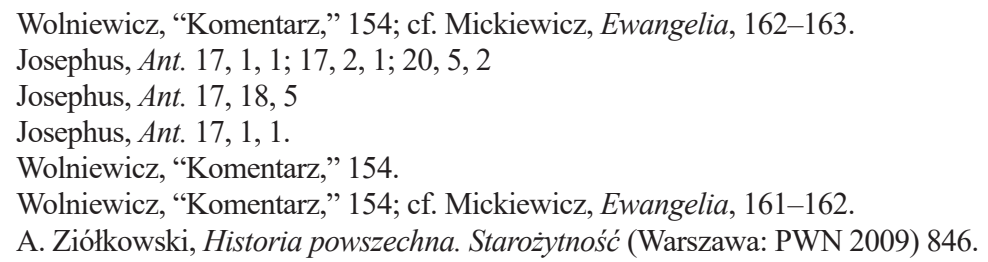


the fact that the description of census is substantiated in Judea already then being a Roman province and Flavius Josephus extensively describes Jews' dissatisfaction who, having participated in the census, knew that they would have to pay higher taxes and quoted fragments from the Jewish Torah which disapproved of such censuses ${ }^{88}$ The address made by the Zealots under the leadership of Judas of Galilee, whose aim was to fight Rome, was a voice of objection against this census. The more ruthless Sicarii later splintered out from the Zealots. ${ }^{89}$ Both groups played a key role in the Jewish Revolt against Rome in 66-73 AD. ${ }^{90}$

Tiberius, who took over as emperor in $14 \mathrm{AD}$, listened to Sejanus's opinions (prefect of the Pretorian Guard) about Jews, which will reinforce the negative opinion about the anti-Roman attitudes of the residents of the Judean province during evangelical events. ${ }^{91}$ Tax burdens were one of the most direct reasons of Jews' reluctance to the occupant.

\section{Roman Tax Law in Roman-Occupied Judea}

The tax terminology of ancient Rome is reconstructed in three terms: vectigal, tributum, and stipendium. ${ }^{92}$ As emphasized by Anna Pikulska-Radomska, the few terms that make up the Latin dictionary of fiscal economy are, naturally, ambiguous, and also their meanings have changed in time and differ from the Greek dictionary which had different names for each levy or a group of levies. ${ }^{93}$

Tributum civium romanorum (tributum ex censu) originally meant a levy paid by patres familias relevant to their census. ${ }^{94}$ The tribute was associated with financing military needs and collected when the treasury was empty. The sum of expected proceeds was divided between individual classes and centuriae. At least twice in the Roman history, that is in $293 \mathrm{BC}$ and $186 \mathrm{BC}$, were unused means returned to the citizens after a victorious war. ${ }^{95}$ After victory in the Battle of Pydna in $167 \mathrm{BC}$, tributes were no longer collected from Roman citizens and the levies taken from the conquered were enough to cover costs. When after 124 years tibu-

\footnotetext{
88 Grant, Dzieje, 270; cf. Ciecieląg, Polityczne, 98-99, 102, 107.

89 Grant, Dzieje, 270.

90 Ciecieląg, Polityczne, 16, 44-45.

91 Grant, Dzieje, 270.

92 A. Pikulska-Radomska, Fiscus non erubescit. O niektórych italskich podatkach rzymskiego pryncypatu (Łódź: Wydawnictwo Uniwersytetu Łódzkiego 2013) 12-38; cf. Ł.J. Korporowicz, "Roman Tax Policy in Roman Britain," RIDA 61 (2014) 235-236.

93 Pikulska-Radomska, Fiscus, 12.

94 Pikulska-Radomska, Fiscus, 29.

95 A. Pikulska-Radomska, "Uwagi o rzymskim fiskalizmie epoki wczesnego cesarstwa," Studia Iuridica Toruniensia 10 (2012) 38.
} 
tum ex censu was again collected for a short period of time, it was met with citizens' dissatisfaction. ${ }^{96}$ The term tributum was applied to define provincial taxes: the land-tax (tributum soli) and the poll-tax (tributum capitis). ${ }^{97}$

The term vectigal, alis (which most often appears in pluralis-nominativus: vectigalia) meant all state revenues save for citizens' tributes and later provincial tributes. ${ }^{98}$ It had different content depending on how the state construed the structure of their revenues, in which public revenues were initially predominant (fees paid by private individuals who used ager publicus, who later got a permit from public authorities to e.g. cultivate land, to bring cattle to pastures, to fish, to erect a building or to operate a business in taberna at the market). Only later did taxes begin to dominate in this category. ${ }^{99}$

The vectigalia category included, from royal times, a portiorum-a levy (known in Greece already) which mainly meant: (a) a tax collected on goods transported beyond state borders, borders of individual provinces or groups of provinces, (b) a tax on goods brought in to certain towns, or (c) charges for the use of certain roads or for riding across some bridges. ${ }^{100}$ In the beginning of the principate, Roman citizens were exempt from tribitum and portiorum, but still paid various vectigalia, for example as tax on: liberating slaves (vicesima libertatis), inheritance and legacies (vicesima hereditatium), on persons practising certain professions (vectigal meretricum, vectigal lenonum - tax on porters' daily wages) or on commercial transactions (centesima rerum venalium, quinta et vicesima venalium mancipiorum). ${ }^{101}$

Stipendium originally meant soldiers' remuneration paid to the military from money collected from citizens' tributes. In the time of conquests, it was transferred on levies collected from the defeated, which were in the eyes of the Romans a reward for the victory and served to compensate the layouts incurred earlier, in particular the cost of soldier's pay. ${ }^{102}$ As signalled by Anna Pikulska-Radomska, the term stipendium was used till the end of the republic parallel to tributum to define a provincial tax. ${ }^{103}$ According to the authors, political considerations (associating tributum with a citizens' levy based on consent, whereas stypendium had pejorative undertones) determined the fact that since the time of Octavian Augustus a provincial tax was called tributum. ${ }^{104}$

\footnotetext{
96 Pikulska-Radomska, Fiscus, 36-37

97 Pikulska-Radomska, Fiscus, 37.

98 Pikulska-Radomska, Fiscus, 39.

99 Pikulska-Radomska, Fiscus, 15-16 and 23.

100 Pikulska-Radomska, Fiscus, 20-31.

101 Pikulska-Radomska, Uwagi, 39.

102 Pikulska-Radomska, Fiscus, 37-48

103 Pikulska-Radomska, Uwagi, 39.

104 The view described in: J. France, "Les catégories du vocabulaire de la fiscalité dans le monde romain," Vocabulaire et expression de l'économie dans le monde antique (eds. J. Andreau - V. Chankowski)
} 
In the original question that the Pharisees and the Herodians asked Jesus, which was about having to pay taxes to Ceasar, Luke 20:22 uses the word

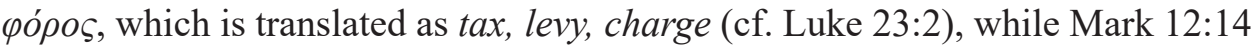
uses a transliterated Latin word $\kappa \tilde{\eta} v \sigma o s$, which also means $\operatorname{tax}$ (cf. Matt 17:25; 22:17.9; Mark 12:14). The tax coin shown to Jesus was dinar (denarius), a small silver coin that had the image of the emperor on the one side and whose value corresponded to an average daily wages in Israel. ${ }^{105}$ It is worth mentioning that the New Testament also describes pieces of silver used to pay to Judas for betraying Jesus (Matt 26:14-15) — that is a silver coin corresponding to the weight of one shekel, that is approx. 1/4 gram; and two small coins, the so-called "widow's mite" (Mark 12:41-44; Luke 21:1-4), one of which is the Greek lepton (the smallest Greek copper coin) and the second one is quadrans (the smallest Roman copper coin). ${ }^{106}$ Jews had to pay taxes to Rome from $63 \mathrm{BC}$; however, when Judea became a Roman province new taxes were imposed on its residents. ${ }^{107}$ Biblical scholars, placing this question in the context of the previously conducted census which fuelled anti-Roman sentiments, assume that both Luke's and Matthew's version might have meant paying taxes in general or paying tributum capitis in particular. ${ }^{108}$ Researchers believe that is was tributum capitis-imposed on Jews by the Romans after establishing the Roman province of Judea and enforced by Quirinius after the census - that was supposed to be the source of major controversies (Matt 17:24-27; Mark 12:13-17; Luke 20:21-26). ${ }^{109}$

One of the most important consequences of encumbering provincial land with tax was the change in the criterion of calculating the levy as it was no longer a citizens' tax paid in relation to the property census, but it was calculated according to the territorial criterion, and in common belief-later expressed by Gaius - provincial lands belonged either to the Roman people or to the emperor. ${ }^{110}$ For this reasons, revenues from provincial tax fed either aerarium populi romani (treasury of the Roman people) if they came from senatorial provinces, or fiscus caesaris (emperor's treasury) if they came from imperial provinces. ${ }^{111}$ For this reason, owners of provincial land, even if they held Roman citizenship, could not be exempt from paying the tribute. ${ }^{12}$

(Bordeaux: Ausonius 2007) 333-368, as quoted in: Pikulska-Radomska, Uwagi, 39; or PikulskaRadomska, Fiscus, 14.

105 McDowell, The New Evidence, 68.

106 McDowell, The New Evidence, 68.

107 Packer - Tenney, Slownik tta Biblii, 127.

108 Wolniewicz, "Komentarz," 124.

109 Cf. Josephus, Ant. 18, 1, 1; cf. Packer - Tenney, Stownik tła Biblii, 127.

110 Pikulska-Radomska, Uwagi, 39.

111 K. Markowska, "Struktura i organizacja prowincji rzymskich - wprowadzenie do zagadnień ustrojowo-prawnych," Krytyka Prawna 7 (2015) 293.

112 Pikulska-Radomska, Uwagi, 38. 
Octavian Augustus's fiscal policy, like other dimensions of his public activity, demonstrates apparent respect for republican institutions while in fact these institutions are being taken over. The princeps gradually took over real control of state finances, formally vested in the senate, whereby fiscus caesaris flexibly took the place of aerarium populi romani ${ }^{113}$ Even though this study intends to describe the fiscal policy with regard to the imperial province, in order to outline a broader context it must be noted that aerarium was divided up into provinciae populi romani, where senators retained control over them and financial proceeds coming from senatorial provinces were transferred to fiscus caesaris. ${ }^{114}$ "Privatisation" of fiscus caesaris was more and more noticeable, which, after Tiberius's reign, was de facto emperor's personal fund made up of reserves, financial proceeds and private and public land. ${ }^{115}$

The increasing of state expenditure, which in the times of Octavian Augustus meant the imposition of new vectigalia on Roman citizens or the development of those already in place, also entailed an increasing-non-proportional to tax capabilities - fiscal burden of a province, which with time started ruining local communities. ${ }^{116}$ The situation was similar in the province of Judea, which after Octavian Augustus's census, administered by prefects who-as historians judge - were people of meagre talent, became the arena of various partisan addresses by the Zealots and later by Sicarians or other small groups of citizens, only to plunge into chaos of an anti-Rome rebellion in the $60 \mathrm{~s} .{ }^{117}$ The leaders of the Sanhedrin also made sure that their own governance-related position among Jews stayed in place. It is for this reason that Jesus's teaching triggered their fear as a potential threat to the convenient status quo.

\section{Roman Judicial Procedure the and the trial of Jesus}

From when the intelligence brought news to the leaders of the Sanhedrin about Jesus's teaching in Galilee seen as a threat to the Jewish order, he was in danger. ${ }^{118}$ Talmudic writings from 70-200 AD, which have provided invaluable contribu-

113 Pikulska-Radomska, Uwagi, 40.

114 Pikulska-Radomska, Uwagi, 40.

115 Pikulska-Radomska, Uwagi, 40.

116 Markowska, "Struktura," 292.

117 Cf. Jońca, Głośne, 185-187; cf. Grant, Dzieje, 270-272, 275-280; cf. Packer - Tenney, Słownik tła Biblii, 127.

118 W. Smereka, “Chrystus w śledztwie Sanhedrynu,” Analecta Cracoviensia 1 (1969) 64; cf. Dąbrowski, Proces Chrystusa, 131. 
tion in proving Jesus's historicity, point out in the text of Sanhedrin 43a the atmosphere of the days preceding Jesus's arrest:

On the eve of Passover Yeshu was hanged. For forty days before the execution took place, a herald went and cried 'He is going forth to be stoned because he has practiced sorcery and enticed Israel to apostasy. And one who can say and - thing in his flavour let him come forward and plead on his behalf.' But since nothing was brought forward in his favour he was hanged on the eve of the Passover! ${ }^{119}$

As has already been mentioned, the Great Sanhedrin was also a tribunal with jurisdiction over Jews residing in Palestine and the diaspora, though the further away from Jerusalem, the lesser the Sanhedrin's influence. ${ }^{120}$ To answer the question about why proceedings in Jesus's case were held first before the Sanhedrin and then before the Roman governor, it is key to explain the Sanhedrin's jurisdiction in the case of Jesus. ${ }^{121}$ Theodor Mommsen, followed by Robert Mayr and Fryderyk Doerr or Eugeniusz Dąbrowski, points out that the Sanhedrin's competence included most serious matters (with a likely death sentence) but the death penalty judgment had to be approved by the Romans. ${ }^{122}$ Giovanni Rosadi assumes that the Sanhedrin had authority in matters punishable by death, but only those that pertained to religion, which is why the Sanhedrin exceeded its competences by conducting Jesus's trial. ${ }^{123}$ Jean Juster and Hans Lietzmann believe that although the Romans gave the Sanhedrin authority to adjudicate not only religious but also criminal matters, including the gravest ones, the Sanhedrin gave Jesus to the Romans to judge and execute the judgment; ${ }^{124}$ or — as pointed out by Maciej Jońca - it recognized Jesus's guilt and passed the judgment but asked the governor to exercise the punishment. ${ }^{125}$ In the context of the hypotheses argued above and reconstructing Sanhedrin's competences, we must believe it reasonable - as also acknowledged by majority of exegetes - that the hearing before the Sanhedrin involved information-giving, though was kept in the convention of a trial and was intended to convince the Jewish elders that Jesus - a threat - must be got rid of. ${ }^{126}$ Due to Jesus's popularity among the people, leaders of the Sanhedrin did not want to take full responsibility for his death, whereby they wanted to lead to his execution to be carried out by the Romans. ${ }^{127}$

119 McDowell, The New Evidence, 58

120 Gnutek, "Środowisko Nowego Testamentu," 36.

121 Ch.E. DeLand, The Mis-Trials of Jesus (Boston, MA: Bodger 1914) 70-79.

122 As quoted in: W. Smereka, "Proces Chrystusa w świetle najnowszych badań," RBL 15 (1962) 155.

123 Smereka, "Proces Chrystusa," 155.

124 Smereka, "Proces Chrystusa," 155.

125 Jońca, Głośne, 195.

126 Jońca, Głośne, 196; cf. Sobczyk, Proces, 238.

127 Jońca, Glośne, 196. 
Annas, despite being taken off the office by Valerius Gratus, was the actual leader of the Sanhedrin's policy and its most influential member. ${ }^{128}$ This is why after Jesus was arrested he was brought before Annas and only later before the officially governing Caiaphas (John 18:12-13.24; cf. Luke 3:2). Also, Annas is believed to be the inspirer of criminal proceedings against Jesus. The following stages are identified in these proceedings, commonly known as the Trial of Jesus: (1) arrest (Matt 26:47-56; Mark 14:43-52; Luke 22:47-53; John 18:1-12), (2) police proceedings before Annas (John 18:12-14.19-24), (3) proceedings before the Jewish tribunal and Sanhedrin's judgment - religious trial (Matt 26:57-68; Mark 14:53-65; Luke 22:66-71), (4) proceedings before the Roman tribunal and (5)judgment (Matt 27:1.11-31; Mark 15:1-5; Luke 23:12-25; John 18:28-19:16). ${ }^{129}$ However, if we believe, as some biblical scholars wish, that the hearing before Annas was part of proceedings before the Sanhedrin, then we can identify four stages, which would correspond to the Talmud's account. ${ }^{130}$

Jesus's arrest happened at night, in the Garden of Gethsemane and Jesus was identified to Sanhedrin's envoys by Judas's kiss (Matt 22:49; Mark 14:45; Luke 22:47), which was part of salutatio - a greeting ritual among friends common in antiquity. ${ }^{131}$ Jesus identified like this was arrested by Jewish soldiers, temple servants and other Sanhedrin's envoys who accompanied Judas. ${ }^{132}$ According to some researchers who take John 18:3.12 into account, Roman soldiers also took part in Jesus's arrest. ${ }^{133}$

In the context of the course of proceedings before the Jewish tribunal, in the aspect of the Roman trial of Jesus, a matter of interest to us is for what the Jews sentenced Jesus to death. ${ }^{134}$ Annas did not present any charges to Jesus, but rather tried to hear something form Jesus that he could use as a charge. ${ }^{135} \mathrm{In}$ those times, in a Jewish criminal trial, in fact like in a Greek or a Roman trial, it was the witnesses who acted as prosecutors, thus Jesus shifted the onus probandi of the crime onto Annas referring him to evidence from possible witnesses who were to provide proof of his guilt. ${ }^{136}$ Due to its inconsistency, witness testimony

128 Wolniewicz, "Komentarz," 278.

129 Smereka, “Chrystus”, 80; cf. S. Mędala, Ewangelia wedtug świętego Jana. Rozdziaty 13-21 (NKB. NT 4/2; Warszawa: Edycja Świętego Pawła 2010) 179-189, 192-203.

130 Smereka, “Chrystus," 63; cf. Deland, The Mis-Trials, 50-55.

131 Kupiszewski, "Nowy Testament," 22.

132 Jońca, Głośne, 193; cf. Święcicka-Wystrychowska, Proces, 71.

133 The thesis shared by i.a. Giuseppe Riciotti, Weddig Fricke; opposite view: Dąbrowski, Proces Chrystusa, 133; cf. Sobczyk, Proces, 235.

134 M. Skierkowski, "Wiarygodność historyczna procesu i śmierci Jezusa: (synteza fundamentalnoprawna)," Studia Teologiczne 19 (2001) 95.

135 Kupiszewski, "Nowy Testament," 22; cf. J.E. Richards - S. Srinivasa Aiyar, The Illegality of the Trial of Jesus (Wolcott, NY: Scholar's Choice 2015) 25.

136 Kupiszewski, "Nowy Testament," 22. 
before the Sanhedrin did not allow Jesus to be sentenced. ${ }^{137}$ Only Jesus's affirmative answer to Caiaphas's question about whether he was the Messiah and Son of God allowed the issuance of a conviction for blasphemy (Matt 26:63-66; Mark 14:61-64; Luke 22:67-71). Jesus's admitting that he was the Messiah, thus king of the Jewish nation, did not still allow for the conviction, but his calling himself Son of God could have been read as blasphemy. ${ }^{138}$ Though still, even here the Jewish law prescribed that such declaration should include the term Yahweh and the Jewish punishment for blasphemy was death by stoning. ${ }^{139}$

With regard to the Roman stage of proceedings, Maciej Jońca, analysing evangelical data (Mark 15:15; Matt 27:6; Luke 23:25; John 18:16) and referring to Tacitus's works, believes that the thesis that "the trial of Jesus was not a trial, but an administrative procedure during which his fate was determined in a fast-track manner" is valid. ${ }^{140}$ However, based on Mark Sobczyk's critical analysis of many relevant opinions of researchers, it seems substantiated to acknowledge a thesis investigated by i.a. Paulina Święcicka-Wystrychowska, that the proceedings before Pilate were the only legal trial of Jesus, conducted according to the cognitio extra ordinem (a model already in place in the principate next to the formulary system) - a less formalised procedure for examining disputes. ${ }^{141}$ Analysing the trial of Jesus in the angle of basic rules of these proceedings (public, oral and direct), the researcher notes that all these principles were observed in Jesus's trial. However, when it comes to the principle of publicity we must note that the trial was actually partially covert owing to the fact that Jews were not allowed to participate in the hearing of Jesus inside the praetorium as they would have dishonoured their ritual purity associated with the coming Pesach, though they were present in the Lithostrotos during the announcement of the judgment. ${ }^{142}$

When we ask about the mode of initiating proceedings against Jesus (Roman criminal proceedings could be initiated in the following modes: complaint, denunciation or inquisition) we must note, following Adrian N. Sherwin-White, that the complaint mode fully dominated in the early principate. ${ }^{143}$ In order for a governor to proceed to examining a case, under his imperium, equipped with arbitrium iudicantis, delatio (reporting) understood as accusatio

137 Jońca, Gtośne, 195.

138 DeLand, The Mis-Trials, 108-116.

139 Jońca, Gtośne, 195; cf. P. Łabuda, "Proces Jezusa w przekazie Talmudu," Zagadnienia Filozoficzne w Nauce 57 (2014) 130-136.

140 Jońca, Gtośne, 205.

141 Sobczyk, Proces, 242 and 238; cf. DeLand, The Mis-Trials, 171-178; Święcicka-Wystrychowska, Proces, 83; cf. R.P. Booth, "We Have a Law...: The Trials of Jesus of Nazareth," The Denning Law Journal 6/1 (1991) 14-15; cf. Kolańczyk, Prawo, 106.

142 Jońca, Gtośne, 196.

143 Sherwin-White, Roman Society, 21-23. 
(accusation) was necessary, later upheld in the trial by those reporting. ${ }^{144}$ From the procedural point of view, Pilate's question about what Jews accuse Jesus of and their response presenting the accusations (John 18:30-31) must be considered as the initiation of the inquiry (causae cognitio), and the charges themselves as the first procedural step-accusatio. ${ }^{145}$

However, it is noted that Jews modify their accusations slightly before Pilate, which became a basis for the conviction issued before the Sanhedrin. In the consistent account of the Evangelists, there is no talk about Jesus's recognizing himself as Son of God in proceedings before Pilate, but he is presented as a person "perverting $[\ldots]$ nation, forbidding $[\ldots]$ to pay taxes to the emperor, and saying that he himself is the Messiah, a king" (Luke 23:2). It is determined by the fact that accusations formulated before the Roman tribunal had to be sanctioned in the Roman law, not the Jewish law. Pursuant to the specific characteristics of the criminal process in the first century, the High Priest and a few elders of the Council (the accusers) presented specific events, and Pilate (regular judge in all criminal cases examined in a given province) matched the facts to the state of affairs finding the provision violated in Roman law. ${ }^{146}$ We do not know whether or not Pilate appointed a concilium - a personal advisory council made up of lawyers who provided counsel to him because the judge himself was not a lawyer. ${ }^{147}$ Accusations formulated by the Jews, accommodated in the category of crimes against the state, punishable by death corresponded to offences such as: (a) threatening public security, safeguarded by provincial governor, by calling for a rebellion against imperial authority (seditio), (b) calling for not paying taxes, which undermines the emperor's treasury (fiscus caesaris), or (c) impersonation of a king-lese-majesty crime (crimen laese maiestatis). ${ }^{148}$ Thus the elements of a complaint in cognition proceedings were satisfied, that is naming the accused and the act he is accused of by a detailed description of his behaviour.

It is difficult to decide on the basis of evangelical evidence whether the socalled formalities of the complaint were fulfilled (solemnia accusationis), which included: inscriptio (entering the complaint in the register of trials after it has been deemed admissible), subscriptio (the accuser's confirmation of information contained in the complaint and in the inscriptio, which was the repetition

144 Booth, We Have a Law, 15; cf. Święcicka-Wystrychowska, Proces, 97.

145 DeLand, The Mis-Trials, 190 and 201-203; cf. Święcicka-Wystrychowska, Proces, 99; cf. Paulus, Der Prozess, 12-17.

146 Sherwin-White, Roman Society, 24-25, 50-51; cf. Paulus, Der Prozess, 23.

147 Święcicka-Wystrychowska, Proces, 104; cf. Dajczak - Giaro - Longhamps de Bérier, Prawo, 49.

148 Jońca, Gtośne, 197; cf. Święcicka, Proces, 102-103; cf. K. Amielańczuk, "Teoretyczny model przestępstwa prawa publicznego (crimen publicum) autorstwa Claudiusza Saturninusa (D. 48,19,16) a współczesna nauka o przestępstwie karnym," Annales Uniwersitatis Mariae Curie-Skłodowska 68/1 (2019) 29-30. 
of the complaint) and cautio (an oath taken by the accuser that he will support the accusation till the end of the proceedings). ${ }^{149}$

When it comes to the obligation to provide and take the evidence (probatio) in a complaints procedure, there was a rule (as has already been mentioned) that this obligation rested with the parties and the main means of evidence, next to documents (documenta) and witness testimony (testimonia) or other material evidence, involved the hearing of the accused (interrogatio, quaesitio, percontatio). ${ }^{150}$

Pilate begins the interrogation carried out after admitting the complaint with a question "Are you the king of the Jews?," to which Jesus gives an affirmative answer (Matt 27:11; Mark 15:2; Luke 23:3; cf. John 18:33-34.37). According to Matthew's and Mark's account, Pilate repeats the question, while according to John he repeats the question twice and gets the same answer from Jesus, which scholars interpret as resignation from the right to protection strictly adhered to in Roman law. ${ }^{151}$ Answering Pilate's question affirmatively and thus performing confessio that his kingdom in not of this world (John 18:36), Jesus ultimately convinces Pilate of his innocence, who then performs absolutio towards the accusers - declaration of no proof of guilt of the accused (John 18:38). ${ }^{152}$

When the accusers raise a new allegation that Jesus stirs up the people (Luke 23:5), Pilate — according to Luke's account—using the fact that Jesus was a Galilean, changed forum and sent Jesus to Herod Antipas - ruler of Galilee (Luke 23:7). ${ }^{153}$ When it comes to jurisdiction (forum competens) in the trial of Jesus, we shall limit the discussion to the fact that Pilate adjudicated in Jesus's case on the basis of forum apprehensionis/deprehensionis (the place of capturing Jesus who was then in Jerusalem) and when Jesus's accusers did not want to give up, he referred to the criterion of territorial jurisdiction (most frequently applied in the principate) that is the offender's place of residence (forum domicilii). ${ }^{154}$ Herod's sending Jesus back to Pilate needs to be explained - as noted by Waldemar Chrostowski and Marek Kuryłowicz - by the fact that Herod might not have wanted to step into Pilate's competences who had already started the trial, or perhaps he could have felt not competent at all to adjudicate as he did not hold imperium. ${ }^{155}$ However, some researchers note here that Pilate, sending the prisoner to Herod, somehow gave him the right to exercise his imperium. ${ }^{156}$

149 Święcicka-Wystrychowska, Proces, 101.

150 Święcicka-Wystrychowska, Proces, 105.

151 Cf. M. Mozgawa-Saj, "Rzymskie korzenie zasady domniemania niewinności i prawa oskarżonego do obrony," Zeszyty Naukowe Uniwersytetu Rzeszowskiego 22 (2018) 104-113.

152 Kupiszewski, "Nowy Testament," 25; cf. DeLand, The Mis-Trials, 192.

153 Jońca, Gtośne, 201.

154 Święcicka-Wystrychowska, Proces, 77 and 110.

155 The authors' opinion quoted after: Święcicka-Wystrychowska, Proces, 110; cf. E.Z. Friedler, "The Trial of Jesus as a Conflict of Laws," Irish Jurist 32 (1997) 417-419.

156 Dąbrowski, Proces Chrystusa, 201. 
The flogging (fustigatio) ordered by Pilate after sending Jesus off to Herod (Luke 23:14-16) was used as punishment for minor offences, introduction to the main punishment or a form of rebuke or warning. ${ }^{157}$ According to biblical scholars, the flogging ordered against Jesus was to be the form of satisfaction for Pharisees and a sign that Pilate believed their accusation as serious and well-founded, not thoughtless, which they could conclude from the very decision about releasing Jesus. ${ }^{158}$ Pontius Pilate's certain submissiveness to the Jews, observed during Jesus's trial, is most likely due to the fact that - as emphasized in sources - he was servile towards the emperor and was scared to wrong Tiberius. Moreover, after a series of earlier unfortunate decisions dictated by hatred towards Jews (e.g. ordering soldiers from the Antonia Fortress to carry the bust of emperor Tiberius ceremoniously on Day of Atonement, which lead to Jewish riots), he was afraid that showing leniency to Jesus would cause another outburst of discontent. ${ }^{159}$ This is why when Pilate makes another attempt to release Jesus by offering to let free Jesus or Barabbas - a rebel fighting against Rome, the Jews demand that Barabbas be released (Matt 27:17-18.20-22; Mark 15:6-9; Luke 23:18-19; John 18:38-40), invoking Pontius Pilate's fear and suggesting that if he fails to do what they request, he is not friend of Caesar (amicus caesaris) that is his adherent, political supporter or confidant (John 19:12). ${ }^{160}$ However, as noted by Maciej Jońca who argues with the idealization of Pilate in the gospels, "if the governor pretended that he was striving to release the prisoner put before him, he did so to spite the Jews rather than materialize the sense of justice." ${ }^{161}$ Biblical scholars view the custom of releasing a prisoner on a holiday, described in the gospels, as a practice emerged during the Hasmonean rule, which the Romans found and upheld, as is to be proven by words of Pilate himself in John 18:39. ${ }^{162}$ Roman law scholars, reserving that Roman legislature did not know the general authority to grant amnesty, which rested with provincial governors, attempt to analyse Pilate's amnesty in the context of the Roman institution of abolitio pubblica. ${ }^{163}$ This attempt, resulting in many differing interpretations and reservations in the context of cognitio extra ordinem regarding Jesus or the possible trial of Barabbas, leads Paulina Święcicka-Wystrychowska to a conclusion that "precise qualification of this incident in the trial is not possible" and she believes it most probable that "the governor of Judea had the authority which would allow him to apply abolitio publica, or even indulgentia in a certain particular case, [...] [and]

157 Paulus, Der Prozess, 12-13; cf. Święcicka-Wystrychowska, Proces, 111.

158 Wolniewicz, "Komentarz," 211.

159 Packer-Tenney, Stownik tła Biblii, 128; cf. Paulus, Der Prozess, 6-8.

160 Sherwin-White, Roman Society, 46-47.

161 Jońca, Głośne, 200.

162 Wolniewicz, "Komentarz," 136-137.

163 Święcicka-Wystrychowska, Proces, 112 
such authority would have to be granted to the prefect expressly, by means of a special caesarean mandate." 164

In the situation described above, abolitio publica could be treated-next to the accuser's withdrawal of the complaint (abolitio privata destirare) or the death of the party (abolitio ex lege) - as one of three extraordinary measures to close the cognitio extra ordinem inquiry, alternative to the issuance of a judgment as a regular mode of closing proceedings. ${ }^{165}$ Pilate, in consideration of lack of these premises and in fear of being accused of disloyalty to Caesar, washed his hands, which is associated with the Roman custom of reconciliation or even expiatory purification lustratio expiatoria, and then, closing the cognition process, issued a convicting (condemnatus) sentence (sententia/verdict) of crucifixion. ${ }^{166}$ According to researchers, Pilate might have applied a shorter formula of the sentence, which would have read: "Ibis ad crucem" or "Abi in crucem." 167 If he opted for a longer formula, it could have been: "Condemno. Ibis ad crucem. Lictor/Miles conliga manus. Verberetur." 168

Since the trial of Jesus was held in the cognition extra ordinem mode, we are left with a question of why suitable appeal (apellatio) was not filed? Appeal to the emperor against a judgment issued by a governor was admissible, though initially only for Roman citizens and with limitations. However, Jesus, as a peregrine, did not have the right of appeal and validity of Pilate's judgment was understood as a non-challengeable decision that could not be quashed in separate proceedings, and once the sentence was issued, the next phase began-enforcement proceedings, that is the immediate public execution of the conviction. ${ }^{169}$

Death by crucifixion (crucifixio), applied by the Romans as one of the most severe punishments, was most likely first applied by the Med People and by Persians, whereas the Romans were to come across it during the Punic Wars. ${ }^{170}$ The Gospels also mention a few other Roman customs that accompanied crucifixion in the context of Jesus's death, such as: (a) crurifragium (crushing the convict's bones by clubs to speed up his death), which was not done to Jesus owing to his quick passing (John 19:31-33); (b) giving the convicts posca (a mixture of vinegar or sour wine, water and eggs), a drink given to Roman soldiers to sober up, especially in eastern provinces (Mark 15:36; Luke 23:36; John 19:28-29); or (c) dividing convict's robes between four soldiers who had flogged and cru-

\footnotetext{
164 Święcicka-Wystrychowska, Proces, 117.

165 Święcicka-Wystrychowska, Proces, 117.

166 Jońca, Głośne, 205; cf. Booth, We Have a Law, 20-21; cf. Święcicka-Wystrychowska, Proces, 125-126; cf. Jońca, Prawo rzymskie. Mirabilia, 87-88.

167 Thesis professed by i.a. Waldemar Chrostowski, as quoted in: Święcicka-Wystrychowska, Proces, 130.

168 Thesis of Marcello Craveri, as quoted in: Święcicka-Wystrychowska, Proces, 130.

169 Święcicka-Wystrychowska, Proces, 131.

170 Jońca, Gtośne, 205-206; cf. Friedler, "The Trial," 424.
} 
cified him. ${ }^{171}$ The Romans, who used to leave bodies of convicts hanging on the cross so that they rot and be pecked away by birds, allowed to have the bodies taken down the very same day in Judea due to Jewish customs and in the case of Jesus of Nazareth - due to the approaching paschal feast. ${ }^{172}$ Convicts were usually buried at the place of execution. Researchers believe that even though bodies could have been given by an official act of grace to have them buried, in the case of those convicted for crimen laese maiestatis such requests were mostly rejected, whereby Pilate's permission to give Jesus's body-for the purpose of burial - must be seen as an extraordinary decision. Even if for scientific integrity we need to take into account the substantiated view-for example thanks to John Granger Cook's scholarly argumentation - that it was not crimen laese maitestatis that provided a basis for Jesus's conviction, the fact of Jesus's funeral is rather historically certain, as admitted by Cook himself who writes that this issue "in not out of the question as archeology shows." 173

\section{Conclusion}

The taking up of the subject matter of the presence of Roman public law in a dayto-day life in Judea, which had previously been addressed by many archaeologists, biblical researchers, historians or philologists, would deem another study to share the fate of works that are chronicle-like or fragmentary. In the face of a multitude of studies and a lack of new archaeological conclusions, it would seem pointless to describe comprehensively the same institutions to reproduce well-known findings of biblical or Roman researchers. The point of this study was saved thanks to the research question that profiles the analysis and is laid down in the introduction, which assumes treatment of elements of Roman institutions described in the gospels as inspiration to describe their legal and historical context.

A not obvious, though important, element of this context comes in the person of Herod the Great, who is only mentioned in the gospels towards the end of his rule, but the history of his collaboration with the Romans and the form he managed to give to his kingdom determine further history of Judea, now as a Roman province, and strongly affects how the Jews were treated by the Romans who, despite having the worst opinions on them, gave them an array of rights not enjoyed in other provinces. The next not so apparent element of this

171 Święcicka-Wystrychowska, Proces, 146-147.

172 Jońca, Glośne, 207-208.

173 J.G. Cook, "Crucifixion and Burial," NTS 57 (2011) 197-199. 
context involves the history of Octavian Augustus's gaining power, who, while ostensibly respecting republican institutions, would de facto reinforce the basis of monarchical authority. This political and systemic climate of the early principate directly affected the structure of power and the political and administrative climate of the province of Judea (section 1) and as such seems to determine the appropriate contemporary understanding of evangelical events.

The Jews' attitudes towards the Romans involve reluctance, present as early as from Pompey's conquests, which increasingly transformed-especially after the establishment of the province of Judea - into open revolts whose direct cause included mainly: unprecedented increase of tax burdens imposed after the census described in the gospels or behaviours of the governors of Judea who did not respect the Jewish religion or tradition. In this aspect, the census (section 2) and the tributum capitis (section 3) paid by residents of Judea, which have been described in this study, seem to be further elements that prescribe the contemporary understanding of the gospels.

The fragment devoted to the Roman trial of Jesus (section 4) is the most reproductive in this study (due to the vast number of relevant studies), though structurally necessary due to its historical significance. The modern day understanding of evangelical events is especially aided by the legal qualification of two stages of criminal proceedings against Jesus of Nazareth, i.e. before the Jewish Sanhedrin and before the Roman governor (for example in the context of attempts-known from the past - to attribute liability for the death of Jesus to the Israelites; or, in consideration of attempts to re-initiate the trial of Jesus, reference to the jurisdiction of the Italian judiciary as a possible legal successor of the Roman empire). Even though difficulties in reconstructing the Sanhedrin's then competences in the case of Jesus do not allow a precise decision, the thesis that is considered the most proven says that the trial before the Roman governor conducted according to cognitio extra ordinem was the only legal trial against Jesus. The legal and historical context of these proceedings, extended here in the description of their certain elements, also should be seen as another element that prescribes the correct understanding of evangelical events today.

Given the above, regardless of whether the gospel is read by a theologian or a lawyer, it may be concluded that the legal and historical context of the gospel, determined by the description of elements of the legal or political and systemic order of ancient Rome selected in this paper, is a necessary background for the correct understanding of the gospel today. Without knowledge on how the system of the then principate affected the political and administrative climate of the province of Judea it is impossible to understand the Jews' resentment towards the Romans, often transforming into a revolt or intensified by increasing fiscal burdens, where the Romans granted the Jews more freedom than they did to any other conquered nation. In turn, without the understanding of this 
phenomenon it is impossible to comprehend the complexity of expectations of the Messiah to come, and in effect - the ambivalent acceptance of Jesus's eschatological teaching. This ambivalence was the reason for the ease with which the "Master Teacher," commonly admired, was quickly and equally commonly regarded as a criminal. Knowledge of these contexts allows us to better understand the determination of Jesus's accusers and their argumentation, used both in the proceedings before the Sanhedrin and before Pilate. Examination of the proceedings before Pilate in terms of individual stages of the cognitio extra ordinem procedure allows for a better insight into the behaviour and statements of Jesus of Nazareth himself and thus better understanding of the essence of his mission. It is also possible to look at the figure of Pilate, who represents the essence of labile human nature, which, though strives for the good, often abandons the objectivity of judicial rulings in favour of convenient compromises that do not require sacrifice.

Translated by Agnieszka Kotula-Empringham

\section{Bibliography}

Altaner, B. - Stuiber, A., Patrologia (Warszawa: Instytut Wydawniczy PAX 1990).

Amielańczuk, K., "Teoretyczny model przestępstwa prawa publicznego (crimen publicum) autorstwa Claudiusa Saturninusa (D. 48,19,16) a współczesna nauka o przestępstwie karnym," Annales Uniwersitatis Mariae Curie-Skłodowska 68/1 (2019) 19-33.

Booth, R.P., "We Have a Law...: The Trials of Jesus of Nazareth," The Denning Law Journal 6/1 (1991) 1-21.

Braunert, H., "Der römische Provinzialzensus und der Schätzungsbericht des Lukas-Evangeliums," Historia. Zeitschrift für alte Geschichte 6 (1957) 192-214.

Bravo, B., "Reformy Polityczne Solona a struktura wspólnoty obywateli ateńskich w okresie archaicznym," Przeglad Historyczny 87/2 (1996) 169-205.

Brown, R.E., The Birth of the Messiah. A Commentary on the Infancy Narratives in the Gospels of Matthew and Luke (New York: Doubleday 1977).

Ciecieląg, J., Polityczne dziedzictwo Heroda Wielkiego. Palestyna w epoce rzymsko-herodiańskiej

(Kraków: Wydawnictwo Naukowe Akademii Pedagogicznej w Krakowie 2002).

Cook, J.G., "Crucifixion and Burial,” New Testament Studies 57 (2011) 193-213.

Dajczak, W. - Giaro, T. - Longhamps de Bérier, F., Prawo rzymskie. U podstaw prawa prywatnego, 3 ed. (Warszawa: PWN 2018).

Dąbrowski, E., "Nowy Testament," Collectanea Theologica 17/4 (1936) 530-550.

Dąbrowski, E., Życie Jezusa Chrystusa w opisie ewangelistów (Poznań: Pallottinum 1951).

Dąbrowski, E., Nowy Testament na tle epoki (Poznań: Księgarnia św. Wojciecha 1965).

Dąbrowski, E., Proces Chrystusa w świetle historyczno-krytycznym (Poznań: Księgarnia św. Wojciecha 1965).

Dąbrowski, E., Dzieje Pawła z Tarsu (Warszawa: Teologia Polityczna 2013). 
DeLand, Ch.E., The Mis-Trials of Jesus (Boston, MA: Badger 1914).

Duncan, J. - Derret, M., Law in the New Testament (Eugene, OR: Wipf \& Stock 2005).

Flavius Josephus, The Antiquities of the Jews [Ant.], https://www.documentacatholicaomnia.eu/ 03d/0037-0103,_Flavius_Josephus,_The_Antiquities_Of_The_Jews,_EN.pdf [access: 30.06.2021].

Friedler, E.Z., "The Trial of Jesus as a Conflict of Laws," Irish Jurist 32 (1997) 398-438.

Gnutek, W., "Środowisko Nowego Testamentu,” Wstęp do Nowego Testamentu (ed. F. Gryglewicz) (Poznań: Pallottinum 1969) 11-50.

Grant, M., Dzieje dawnego Izraela (Warszawa: Państwowy Instytut Wydawniczy 1991).

Jaczynowska, M. - Musiał, D. - Stępień, M., Historia starożytna (Warszawa: Trio 2000).

Jaczynowska, M., Historia starożytnego Rzymu (Warszawa: Państwowe Wydawnictwo Naukowe 1974).

Jewish Encyclopedia (The unedited full-text of the 1906 Jewish Encyclopedia) https://www.jewishencyclopedia.com/articles/7689-high-priest [access: 18.06.2021].

Jońca, M., Głośne rzymskie procesy karne (Wrocław: Zakład Narodowy im. Ossolińskich 2009).

Jońca, M., Prawo rzymskie. Mirabilia (Warszawa: Beck 2020).

Klinkowski, J., Herod Wielki i jego epoka (Wrocław: TUM 2007).

Kolańczyk, K., Prawo rzymskie, 2 ed. (Warszawa: PWN 1976).

Korporowicz, Ł.J., "Roman Tax Policy in Roman Britain," Revue Internationale des Droits de l'Antiquitè 61 (2014) 229-251.

Kudasiewicz, J., "Ewangelie synoptyczne," Wstęp do Nowego Testamentu (ed. F. Gryglewicz) (Poznań: Pallottinum 1969) 52-119.

Kupiszewski, H., "Nowy Testament a historia prawa: (wykład z okazji pięćdziesięciolecia pracy naukowej ks. prof. dr Mariana Myrchy)," Prawo Kanoniczne. Kwartalnik prawno-historyczny 29/3-4 (1986) 13-26.

Kuryłowicz, M., "De cadaveribus punitorum. Das römische Recht über die Leichen von wegen der Straftaten genen den Staat verurteilten Personen," Scripta minora selecta. Ausgewählte Schriften zum römischen Recht (Lublin: Verlag der Maria Curie-Skłodowska - Universität 2014) 162-173.

Lo Cascio, E., "The Size of the Roman Population: Beloch and the Meaning of the Augustan Census Figures," The Journal of Roman Studies 84 (1994) 23-40.

Lo Cascio, E., "Il census a Roma e la sua evoluzione dall'età serviana alla prima età imperiale," Mélanges de l'école française de Rome. Antiquité 113/2 (2001) 565-603.

Łabuda, P., "Proces Jezusa w przekazie Talmudu," Zagadnienia Filozoficzne w Nauce 57 (2014) 111-142.

Markowska, K., "Struktura i organizacja prowincji rzymskich - wprowadzenie do zagadnień ustrojowo-prawnych," Krytyka Prawna 7 (2015) 281-308.

McDowell, J. - Wilson, B., He Walked Among Us. Evidence for the Historical Jesus (Nashville, TN: Nelson 1993).

McDowell, J., The New Evidence that Demands a Verdict (Nashville, TN: Nelson 1999).

Mędala, S., Ewangelia wedtug świętego Jana. Rozdziały 13-21 (Nowy Komentarz Biblijny. Nowy Testament 4/2; Warszawa: Edycja Świętego Pawła 2010).

Mickiewicz, F., Ewangelia wedtug świętego Łukasza. Rozdziały 1-11 (Nowy Komentarz Biblijny. Nowy Testament 3/1; Warszawa: Edycja Świętego Pawła 2010).

Mozgawa-Saj, M., "Rzymskie korzenie zasady domniemania niewinności i prawa oskarżonego do obrony,” Zeszyty Naukowe Uniwersytetu Rzeszowskiego 22 (2018) 104-113. 
Nörr, D., "Civil Law in the Gospels," Irish Jurist 1/2 (1966) 328-340.

Paciorek, A., Ewangelia wedtug świętego Mateusza. Rozdziaty 1-13 (Nowy Komentarz Biblijny. Nowy Testament 1/1; Warszawa: Edycja Świętego Pawła 2010).

Paciorek, A., Ewangelia wedtug świętego Mateusza. Rozdziały 14-28 (Nowy Komentarz Biblijny.

Nowy Testament 1/2; Warszawa: Edycja Świętego Pawła 2010).

Packer, J.I. - Tenney, M.C. (eds.), Stownik tła Biblii (Polish version edited by W. Chrostowski; trans.

Z. Kościuk) (Warszawa: Vocatio 2007).

Paulus, Ch.P., Der Prozess Jesu - aus römisch-rechtlicher Perspektive (Berlin - Boston, MA: De Gruyter 2016).

Pikulska-Radomska, A., "Uwagi o rzymskim fiskalizmie epoki wczesnego cesarstwa,” Studia Iuridica Toruniensia 10 (2012) 37-49.

Pikulska-Radomska, A., Fiscus non erubescit. O niektórych italskich podatkach rzymskiego pryncypatu (Łódź: Wydawnictwo Uniwersytetu Łódzkiego 2013).

Plezia, M. (ed.), Stownik tacińsko-polski (Warszawa: PWN 2007) I.

Richards, J.E. - Srinivasa Aiyar, S., The Illegality of the Trial of Jesus (Wolcott, NY: Scholar's Choice 2015).

Schäfer, P., The History of the Jews in the Greco-Roman World. The Jesus of Palestine from Alexander the Great to the Arab Conquest (London: Routledge 2003).

Sherwin-White, A.N., Roman Society and Roman Law in the New Testament (Oxford: Clarendon 1963).

Skierkowski, M., "Wiarygodność historyczna procesu i śmierci Jezusa: (synteza fundamentalnoprawna)," Studia Teologiczne 19 (2001) 89-107.

Smereka, W., "Proces Chrystusa w świetle najnowszych badań," Ruch Biblijny i Liturgiczny 15 (1962) 154-160.

Smereka, W., "Chrystus w śledztwie Sanhedrynu," Analecta Cracoviensia 1 (1969) 57-82.

Sobczyk, M., "Proces Jezusa oczami historyka i prawnika," Acta Iuridica Toruniensia 12 (2013) 221-252.

Święcicka-Wystrychowska, P., Proces Jezusa w świetle prawa rzymskiego (Kraków: Wydawnictwo Uniwersytetu Jagiellońskiego 2005; Warszawa: Wolters Kluwer 2012).

Tarwacka, A., “Censoria potestas Oktawiana Augusta,” Zeszyty Prawnicze UKSW 11/1 (2011)359-375.

Tarwacka, A., Prawne aspekty urzędu cenzora w starożytnym Rzymie (Warszawa: Wydawnictwo UKSW 2012).

Treccani. Vocabolario on-line, https://www.treccani.it/vocabolario/censo/ [access: 30.06.2021].

Wolniewicz, M., “Komentarz," Pismo Święte Starego i Nowego Testamentu w przekładzie z języków oryginalnych ze wstępami i zomentarzem 2 ed. (ed. M. Wolniewicz) (Poznań: Księgarnia św. Wojciecha 1982) III.

Wolski, J., "Przedmowa," Prowincje rzymskie i ich znaczenie w ramach Imperium (eds. M. Jaczynowska - J. Wolski) (Warszawa: Zakład Narodowy im. Ossolińskich - PAN 1976) 5-8.

Wolski, J., Historia Powszechna. Starożytność (Warszawa: PWN 1997).

Wołodkiewicz, W. (ed.), Prawo rzymskie. Stownik encyklopedyczny (Warszawa: Wiedza Powszechna 1986).

Zanker, P., August i potęga obrazów (eds. M. Jankowska - E. Dobosz; trans. L. Olszewski) (Poznań: Wydawnictwo Naukowe UAM 1999).

Ziółkowski, A., Historia powszechna. Starożytność (Warszawa: PWN 2009). 
